\title{
EFFECT OF GROSS DOMESTIC REGIONAL BRUTO, PROVINCIAL MINIMUM WAGE, AND INVESTMENT ON LABOR ABSORPTION
}

\author{
Tiara Juliana Jaya* \\ Universitas Islam Negeri Maulana Malik Ibrahim Malang, Indonesia \\ Kholilah \\ Universitas Islam Negeri Maulana Malik Ibrahim Malang, Indonesia
}

\begin{abstract}
The unemployment rate in Indonesia is a classic problem that continues to be reviewed. This study aims to determine the impact of gross domestic product, provincial minimum wage, and labor absorption investment. This research uses quantitative methods and panel data analysis, which is processed using eviews 10, conducted in six provinces in Java in 2013-2019. The study used secondary data from the central statistics agency: labor absorption data, gross regional domestic product, and the provincial minimum wage (UMP). At the same time, investment data obtained the value of domestic investment and foreign investment. The results showed that PDRB and investment had a positive effect on labor absorption. In contrast to these two variables, UMP negatively affects labor absorption. The results of this study are essential for policymakers on labor issues in Indonesia. The suggestion for the next research is to use a broader scope, namely Indonesia. Besides, it is necessary to distinguish the workforce into an educated workforce, a trained workforce, an uneducated workforce, and an untrained workforce.
\end{abstract}

JEL: E20, E23, F66

Keywords: Regional Domestic Product, Provincial Minimum Wage, Investment

\begin{abstract}
ABSTRAK
Tingkat pengangguran di Indonesia merupakan masalah klasik yang terus dikaji penyelesaiannya. Tujuan dari penelitian ini adalah mengetahui dampak upah minimum provinsi, dan investasi terhadap penyerapan tenaga kerja. Penilitian ini menggunakan metode kuantitatif dan analisis data panel dengan bantuan eviews 10. Penelitian dilakukan pada enam provinsi di pulau Jawa pada tahun 20132019, mengggunakan data sekunder yang berasal dari Badan Pusat Statistik untuk data penyerapan tenaga kerja, produk domestik regional bruto (PDRB), dan upah minimum provinsi (UMP). Data investasi didapatkan dari nilai penanaman modal dalam negeri dan penanaman modal asing. Hasil penelitian menunjukkan bahwa PDRB dan investasi berpengaruh positif terhadap penyerapan tenaga kerja. Berbeda dengan kedua variabel tersebut, UMP berpengaruh negatif terhadap penyerapan tenaga kerja. Hasil penelitian ini penting untuk pengambilam kebijakan tentang permasalahan tenaga kerja di Indonesia. Penelitian berikutnya dapat dilakukan dalam lingkup yang lebih luas yaitu Indonesia. Selain itu, perlu dibedakan jenis tenaga kerja menjadi tenaga kerja terdidik, tenaga kerja terlatih, tenaga kerja tidak terdidik, dan tenaga kerja tidak terlatih.
\end{abstract}

Kata Kunci : PDRB, Upah Minimum Provinsi, Investasi

\section{INTRODUCTION}

Indonesia is one of the largest population countries in the world (Hindun, 2019). The high number of people accompanied by the high quality of human resources can be a strength in the State economy. On the other hand, the low quality of human resources leads to many populations not absorbed in the industrial world. Labor absorption is still a significant problem in the Indonesian economy (Budiarto \& Dewi, 2015; Hindun, 2019; Indradewa \& Natha, 2015). The labor absorption problem's impact is the high unemployment rate (Wihastuti \& Rahmatullah,

"Email: tiarajulianajaya@uin-malang.ac.id

Received : 2-10-2020, Accepted : 26-12-2020, Published : 28-12-2020.

P-ISSN : 2087-9954, E-ISSN : 2550-0066. DOI : http://dx.doi.org/10.26418/jebik.v9vi3.42642 
2018). Indonesia's population growth rate is $1.46 \%$ based on East Java BPS (2020), with a population distribution center of $57.48 \%$ in Java island and a population density of 992 people $/ \mathrm{km}^{2}$.

Population density has an impact on the concentration of labor absorption in Java. In 20132019 the average contribution of Java's Gross Regional Domestic Product (PDRB) to Indonesia's GDP was 58.49\%. The high contribution of PDRB in Java is expected to open up new jobs. However, the high contribution of PDRB is inversely proportional to labor absorption, resulting in a higher unemployment rate than the rate of labor absorption (Pangastuti, 2015). Ideal conditions are achieved when economic growth is directly proportional to labor growth.

PDRB represents the amount of added value generated by all business units in a region or the total value of final goods and services (net) generated by all economic units based on East Java BPS (2020). The two benefits of PDRB calculation are determining regional categorization and comparing each period's regional economy (Adisetiawan \& Ahmadi, 2016). Furthermore, the first is to know the regional economy's structure to determine the categorization of the region as industrial, agricultural, and service areas and the contribution of each sector to the regional economy (Adisetiawan \& Ahmadi, 2016). The second is to compare a region's economy each period to inform an increase or decrease in the level of public prosperity in a region (Adisetiawan \& Ahmadi, 2016). PDRB positively affects labor absorption (LA) (Budiarto \& Dewi, 2015; Hartono, Busari \& Awaluddin, 2018; Indradewa \& Natha, 2015; Widjajanto \& Agus, 2020; Ziyadaturrofiqoh, Zulfanetti \& Safri, 2018). In contrast to the study results, Putri \& Soelistyo (2018) mentioned that PDRB negatively affects labor absorption. Differences in the study results show that there are gaps in researching to test the influence of PDRB on labor absorption.

The provincial minimum wage (UMP) is the monthly base wage, including the lowest fixed allowance in a province (Sudiarawan \& Martana, 2019). The minimum wage can ideally meet workers, employers, and job seekers (Sudiarawan \& Martana, 2019). Some studies have suggested that UMP negatively affects labor absorption (Akpansung \& Gidigbi, 2014; Indradewa \& Natha, 2015; Putri \& Soelistyo, 2018; Wihastuti \& Rahmatullah, 2018; Wilis, 2016). In contrast to the research (Lokiman, Rotinsulu, \& Luntungan, 2015; Indradewa \& Natha, 2015; Pangastuti, 2015; Sitompul \& Simangunsong, 2019), there is a positive influence of UMP on labor absorption. The results mention that UMP does not affect labor absorption (Budiarto \& Dewi, 2015; Fachriza \& Moeliono, 2018; Tapparan, 2017). Differences in the study results show that there are still gaps in this study to test UMP's influence on labor absorption.

A good investment climate impacts investor confidence to invest. The investment value affects the number of funds the company gets to develop its business operations, thus enabling labor absorption (Budiarto \& Dewi, 2015). Furthermore, it mentioned that increased investment boosted trade volume and production volume, impacting employment opportunities, increased per capita income, and improved public welfare. Putri \& Soelistyo (2018) mentioned that the increase in investment positively affected labor absorption. The higher the investment value then, the higher the absorption of labor (Romdhoni, 2017). Different influences were found by Budiarto \& Dewi (2015) and Widjajanto \& Agus (2020), who mentioned that investment negatively affects labor absorption. In contrast to the study did not manage to find the effect of labor absorption to investment (Setiawan, Maulida, \& Sandika, 2014; Tapparan, 2017). The study results' difference became a gap in this study to test the influence of investment on labor absorption. 
Based on the background above, there are three objectives in this study. First, know the influence of PDRB on labor absorption. Second, knowing the influence of UMP on labor absorption. Third, knowing the effect of investment on labor absorption. This research is expected to provide input on policymaking related to factors that affect labor absorption in Indonesia.

\section{LITERATURE REVIEW}

\subsection{Labor}

Labor is the most crucial factor in the production process. Law No. 13 of 2003 Article 1 states that labor is every person who can carry out work both inside and outside the working relationship to produce goods and services to meet the community's needs. More detailed Law No. 25 of 1997 states that the working-age is 15 years. In contrast to the Law, Law No. 13 of 2013 does not provide age restrictions in labor definition, but it prohibits children's hiring. Children under Law No. 25 of 1997 on employment are men or women under 15. Based on Law No. 25 of 2007 on employment, Indonesia's working-age limit is 15 years.

Labor absorption is the number of jobs that have been filled, which is reflected in the large number of people working (Budiarto \& Dewi, 2015). The working population is absorbed and spread across various sectors of the economy. The absorption of the working population is due to the demand for labor. Therefore, labor absorption can be said to be labor demand (Budiarto \& Dewi, 2015). To be able to understand labor demand can be approached through production functions. The production function is always stated in the following form:

$$
Q=f(C, L)
$$

Description:

$\mathrm{Q}=$ Total Production

$\mathrm{C}=$ Capital/Capital

$\mathrm{L}=$ Labor

The law of diminishing return in production factors explains the fundamental nature of the relationship between production and labor levels used. If the input is added to its use, while the other inputs are fixed, then the additional output generated from each additional one input unit added initially rises, but after reaching a certain level, the output will decrease further if the input continues to be added. Factors in the production process are production capital and labor capital.

Production capital is real capital goods that include all kinds of goods made to support other goods' production activities, including those that produce services and capital in the form of money available in the company to buy machinery and production factors. Money capital is a fund used to buy capital goods and other production factors. Examples of production capital are real capital goods, i.e., any goods used in production activities to produce other goods and services, such as machinery, power plants, buildings, highways, warehouses, and other equipment.

Labor capital is an essential factor in producing goods and services and investment value factors, raw materials, and technology. The use of labor as a variable in the production process is determined by the labor market in labor wages and output prices (Budiarto \& Dewi, 2015). Wage levels influence labor productivity; therefore, adequate wages significantly affect the production process. Besides, the workforce's appreciation or appreciation can be more valuable than encourages the workforce to be more motivated at work. The nature of the request's function 
depends on the increase in public demand for goods produced by the workforce called "derived demand" (Budiarty, 2018)

The high demand for a company's production output can increase the price of such output. This price increase does not change the workforce's marginal product regardless of the number of workers employed but can increase its production's marginal value (Budiarto \& Dewi, 2015). In this article, liquidity is defined as a condition where the bond transaction can be concluded very fast, and trading in large amounts does not affect much of both bid-ask spread and instrument price (Indradewa \& Natha, 2015). Also, Pangastuti (2015) defined a liquid bond market as a market where the transaction can be concluded at no cost. Therefore, a market with low transaction costs can be considered as a liquid market. In practice, the bond is issued at the primary market and then traded in the secondary market by dealers. Liquidity reflects an issue for secondary rather than primary market.

\subsection{Gross Regional Domestic Product}

PDRB is one of the economic indicators that contain various economic instruments that expose the macroeconomic state with economic growth, per capita income, and various other economic instruments. Widjajanto \& Agus (2020) mentioned that PDRB is an essential indicator of a region's economic condition within a specific time, either using the prevailing price base or constant price. One of the critical functions of PDRB is measuring the economic growth rate (Widjajanto \& Agus, 2020).

BPS (2020) mentions that PDRB has five benefits over its price measurement. First, PDRB, based on the prevailing price (nominal), shows the ability of economic resources generated by a region. Second, GDP on a constant (real) price basis can show the overall economic growth pace or each sector year after year. Third, the distribution of PDRB based on prevailing prices based on the business field shows each business field's economic structure or role in a region of Central Java (BPS, 2020). Fourth, PDRB per capita based on prevailing prices shows the value of PDRB per head or population (BPS, 2020). Fifth, in GDP per capita on a constant price basis, it is beneficial to know the real economic growth per capita of a region's population. Widjajanto \& Agus (2020) mentioned two methods for calculating PDRB: direct and indirect. The indirect method is done by calculating the allocation by allocating GDP to the provincial PDRB or vice versa, i.e., provincial PDRB to PDRB district or city using various production indicators and other indicators suitable as allocators (Widjajanto \& Agus, 2020).

The high number of PDRB can increase the absorption of labor. The results of Budiarto \& Dewi (2015), Fachriza \& Moeliono (2018), Indradewa \& Natha (2015), and Widjajanto \& Agus (2020) mentioned that PDRB has a positive effect on labor absorption. Therefore, the first hypothesis in this study is presented below.

H1: PDRB has a positive effect on labor absorption

\subsection{Provincial Minimum Wage}

Law No. 13 of 2003 on employment states that wages are the worker's right in the form of money, including benefits for workers and their families for their works. The minimum wage is a minimum standard used by employers or industry players to provide wages to workers in their business or work environment (BPS, 2020). The definition of the provincial minimum wage arises due to differences in the fulfillment of each province's needs. The minimum wage policy's primary 
purpose is to protect workers from low wage levels, especially at a time of high labor supply levels, so that wage levels will not continue to decline (Wilis, 2016).

Some studies have suggested that UMP negatively affects labor absorption (Akpansung \& Gidigbi, 2014; Indradewa \& Natha, 2015; Putri \& Soelistyo, 2018; Wihastuti \& Rahmatullah, 2018; Wilis, 2016). Therefore, the second hypothesis in this study is:

H2: UMP negatively affects labor absorption

\subsection{Investment}

Investment is the formation of gross domestic fixed capital covering various types of expenditure for the procurement, manufacture, and purchase of new capital goods, produced domestically / regionally and new and used capital goods originating from other domestic/regional or imported from abroad in units millions of rupiah (Budiarto and Dewi, 2015). Macroeconomic investment is spending on capital equipment, inventory, and structure, including household spending on new homes (Mankiw et al., 2014). Sulistiawati (2012) mentioned that investment activities carried out by the community are continuously able to increase economic activities and employment opportunities, increase national income, and increase the level of public prosperity. Widjajanto \& Agus (2020) mentioned that three critical functions of investment activities are aggregate expenditure components, additional production capacity, and technological development. Furthermore, Widjajanto \& Agus (2020) mentioned that investment could be divided into two: investment in financial assets and investment in rill assets. Investments in financial assets can be divided into two: direct investments can be made by purchasing tradeable and non-tradeable assets, and indirect investments by purchasing securities from investment companies, such as mutual funds.

Putri \& Soelistyo (2018) and Romdhoni (2017) mentioned that the increase in investment positively affected labor absorption. The higher the investment value then, the higher the absorption of labor. Therefore, the third hypothesis in this study is:

H3: Investment has a positive effect on labor absorption

\subsection{Conceptual Framework}

Based on these three hypotheses, the research's conceptual framework in this study is presented in Figure 2.

\section{Independent Variable Dependent Variable}

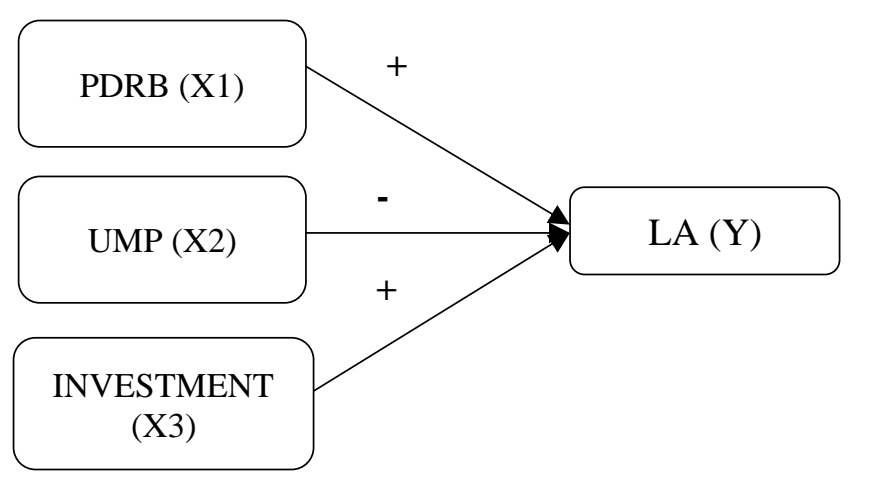

Figure 2. Conceptual Framework 


\section{RESEARCH AND METHOD}

The study used a quantitative descriptive approach and data panel analysis. Data on LA, PDRB, and UMP uses data from the Central Statistics Agency (BPS). Simultaneously, industrial sector investment data is taken from domestic investment data (PMDN) and Foreign Direct Investment (PMA) from 2013 to 2019 in 6 provinces in Java. This study's dependent variables are LA, while the independent variables in this study are PDRB, UMP, and Investment. The data analysis in this study uses multiple regression analysis panel data. The model equations in this study are:

$$
L A_{i t}=\beta_{0}+\beta_{1} P D R B_{i t}+\beta_{2} U M P_{i t}+\beta_{3} \text { Invest }_{i t}+e_{i t}
$$

In the form of natural logarithm models ( $\mathrm{Ln})$, transformations are performed in order for data to be distributed normally. Transformation results are presented in the new equation model as follows:

$$
\operatorname{LnLA}_{i t}=\beta_{0}+\beta_{1} \operatorname{LnPDRB}_{i t}+\beta_{2} \operatorname{LnUMP}_{i t}+\beta_{3} \text { LnInvest }_{i t}+e_{i t}
$$

Description:

$$
\begin{aligned}
& \text { Ln } \quad=\text { Natural logarithm } \\
& \text { LA } \quad=\text { Absorption of industrial labor (soul) } \\
& \text { UMP = Provincial minimum wage (rupiah) } \\
& \text { PDRB = Gross regional domestic product of industrial sector (billion rupiah) } \\
& \text { Invest } \quad=\text { Industrial sector investment (billion rupiah) } \\
& \mathrm{i} \quad=\text { Province } \\
& \mathrm{t} \quad=\text { Year 2013-2019 } \\
& \beta_{0} \quad=\text { intersept (constant) } \\
& \beta_{1}, \beta_{2}, \beta_{3} \quad=\text { regression coefficient of each variable } \\
& \mathrm{e} \quad=\text { error term }
\end{aligned}
$$

\section{RESULTS AND DISCUSSION}

Density on the island of Java affects population density and impacts the concentration of labor absorption in Java Island. In 2013-2019 the average contribution of Java's Gross Regional Domestic Product (GDP) to Indonesia's GDP was 58.49\%. The high contribution of GDP in Java is expected to open new jobs. However, the high contribution of GDP is inversely proportional to labor absorption, so that the unemployment rate is higher than the employment absorption rate (Pangastuti, 2015). Ideal conditions are achieved when economic growth is directly proportional to employment growth.

GDP has a positive effect on labor absorption (LA) (Budiarto \& Dewi, 2015; Hartono et al., 2018; Indradewa \& Natha, 2015; Widjajanto \& Agus, 2020; Ziyadaturrofiqoh et al., 2018). This strengthens the research results conducted by the authors, where GDP affects the absorption of labor on Java's island.

Several studies have shown that UMP negatively affects the absorption of labor (Akpansung \& Gidigbi, 2014; Indradewa \& Natha, 2015; Putri \& Soelistyo, 2018; Wihastuti \& Rahmatullah, 2018; Wilis, 2016). This opinion strengthens the results of the author's research where UMP negatively affects the absorption of labor (LA), but different from previous research results (Lokiman et al., 2014; Indradewa \& Natha, 2015; Pangastuti, 2015). Pangastuti (2015) mentioned that there is a positive influence of UMP affecting the absorption of labor. The results 
Budiarty (2018), Fachriza \& Moeliono (2018) and Tapparan (2017) said the UMP does not affect the absorption of labor.

Increased investment volume and production volume, impacting the expansion of employment opportunities, increased per capita income, and improved people's welfare. Putri \& Soelistyo (2018) mentions that the increase in positive investment affects the absorption of labor. The higher the value of investment then, the higher the absorption of labor. This strengthens the research that the authors do because investment affects the absorption of labor. Different influences were found by Budiarto \& Dewi (2015) and Widjajanto \& Agus (2020), which states that investment has a negative impact on labor absorption. In contrast to the study, Tapparan (2017) was unable to find labor absorption's investment effect.

\subsection{Descriptive Analysis}

The results of the descriptive analysis show in table 1.

Table 1. Descriptive Statistics Research Variables

\begin{tabular}{lcccc}
\hline & LA & UMP & PDRB & Invest \\
\hline Mean & $1,905,412$ & $1,370,033$ & 231,099 & $1,601,132$ \\
Median & $1,604,742$ & $1,000,000$ & 204,383 & $1,218,860$ \\
Maximum & $3,935,610$ & 850,000 & 549,471 & $8,977,714$ \\
Minimum & 262,108 & 630,000 & 9,216 & $7,544,911$ \\
Std. Dev. & $1,276,984$ & $1,269,561$ & 156,536 & $1,311,009$ \\
Skewness & 0.19 & 4.4 & 0.29 & 4.46 \\
Kurtosis & 1.48 & 25.01 & 2.14 & 25.12 \\
Observations & 42 & 42 & 42 & 42 \\
\hline
\end{tabular}

Table 1 shows the average value of LA in 6 Provinces in Java is 1,905,412, the average UMP value is Rp 1,370,033, the average value of PDRB is 231,099 , and the average investment value is 1,601,132. The maximum value of LA is 3,935,610 in West Java Province, and the minimum value of LA is 262,108 in THE Province of Yogyakarta. The maximum UMP value is Rp 850,000 in West Java Province, and the minimum UMP value is Rp 630,000 in East Java Province.

PDRB has a maximum value of 549,471 billion in West Java and a minimum value of 9,216 billion P in Yogyakarta Province. The maximum investment value is Rp 8,977,714 in West Java Province, and the minimum investment value is 7,544,911 billion in the Province of Yogyakarta. After the transformation into the PDRB log form, the four variables' descriptive analysis present in table 2 .

Table 2. Descriptive Statistics Research Variables (LOG)

\begin{tabular}{lcccc}
\hline & LOG(LA) & LOG(UMP) & LOG(PDRB) & LOG(Invest) \\
\hline Mean & 15.28 & 14.14 & 5.36 & 15.20 \\
Median & 6.21 & 6 & 5.31 & 5.31 \\
Maximum & 6.60 & 6.93 & 5.74 & 6.95 \\
Minimum & 5.42 & 5.80 & 3.97 & 5.88 \\
Std. Dev. & 15.11 & 15.10 & 15.19 & 15.12 \\
Observations & 42 & 42 & 42 & 42 \\
\hline
\end{tabular}

Table 2 shows that the average of LA after log transformation is 15.28 , with a maximum value of 6.60 and the lowest value of 5.42. The average UMP value is 14.14 , with a maximum value of 6.93 and the lowest value of 5.80. The average value of PDRB is 5.36, with a maximum 
value of 5.74 and 3.97. The average investment value of 15.20 with a maximum value of 6.95 and the lowest value of 5.88 .

\subsection{Regression Model Estimation Results}

After selecting model testing between Random Effect Model (REM) and Fixed Effect Model (FEM) with the Hausman Test, the best model obtained is the FEM model. Furthermore, the regression test is carried out using the FEM approach. Regression results present in table 3.

Table 3. Regression Test Results with FEM Approach

\begin{tabular}{|c|c|c|c|c|}
\hline \multicolumn{5}{|c|}{ Dependent Variable $=\log (\mathbf{L A})$} \\
\hline Variable & Coefficient & Std. Error & t-Statistic & Prob. \\
\hline $\mathrm{C}$ & $8.399585 * *$ & 0.030143 & 278.6622 & 0.0000 \\
\hline LOG(UMP) & $-0.874935^{* *}$ & 0.003497 & -250.1811 & 0.0000 \\
\hline LOG(PDRB) & $0.561902 * *$ & 0.003243 & 173.2863 & 0.0000 \\
\hline LOG(Invest) & $0.821413 * *$ & 0.003138 & 261.7905 & 0.0000 \\
\hline R-square & 0.999816 & - & - & - \\
\hline Adjusted R-square & 0.999772 & - & - & - \\
\hline
\end{tabular}

This research uses the FEM model, then can be written regression equations as follows:

$\operatorname{LogLA}_{i t}=8.399585+0.561902 \operatorname{LogPDRB}_{\mathrm{it}}-0.874935 \operatorname{LogUMP}_{\mathrm{it}}+0.821413$ LogInvest $_{\text {it }}$

The regression test results in table 3 show that PDRB positively affects the absorption of industrial sector labor. Any increase in GDP by $1 \%$ can increase the absorption of industrial sector labor by $0.56 \%$. UMP negatively affects the absorption of industrial sector labor. This means that any increase in UMP by $1 \%$ will decrease industrial sector labor absorption by $0.87 \%$. Investment has a positive effect on the absorption of industrial sector workers. Any increase in investment of $1 \%$ can increase the industrial sector workforce's absorption by $0.82 \%$.

Table 4 shows that the largest source of influence from the increase in human resources can be the investment value in West Java Province, which is $28.621 \%$. At the same time, the lowest source of the increase in human resources is in West Java Province in the form of UMP of $30.366 \%$.

Table 4. Predictive Value

\begin{tabular}{lccccccc}
\hline Province & \multicolumn{3}{c}{$\begin{array}{c}\text { Coefficient } \\
\text { UMP }\end{array}$} & $\begin{array}{l}\text { PDRB } \\
(\boldsymbol{\%})\end{array}$ & $\begin{array}{l}\text { Invest } \\
(\boldsymbol{\%})\end{array}$ & Mean LA & \multicolumn{2}{c}{ Predict. Value of LA * $(\%)$} \\
& -0.87 & 0.56 & 0.82 & 549,115 & -4.777 & 3.075 & 4.503 \\
DKI Jakarta & -0.87 & 0.56 & 0.82 & $3,490,401$ & -30.366 & 19.546 & 28.621 \\
Jawa Barat & -0.87 & 0.56 & 0.82 & $3,098,789$ & -26.959 & 17.353 & 25.410 \\
Jawa Tengah & -0.87 & 0.56 & 0.82 & 486,226 & -4.230 & 2.723 & 3.987 \\
DI Yogyakarta & -0.87 & 0.56 & 0.82 & $2,653,167$ & -23.083 & 14.858 & 21.756 \\
Jawa Tengah & -0.87 & 0.56 & 0.82 & $1,154,834$ & -10.047 & 6.467 & 9.470 \\
Banten & -0.87 & UMP & PDRB & Invest \\
\hline
\end{tabular}

Description: * Projected UMP, PDRB, and Invest in the event of a 1\% increase in labor absorption.

\subsection{Classic Assumption Test}

The probability value for the normality test is 0.673936 . Probability value $0.637634>0.05$ then normal distributed data. So it can be concluded that normally distributed assumptions in the model are met. Table 5 shows that the relationship between free variables is smaller than $0.8(\mathrm{r}<$ 
0.8 ), which means the model does not contain multicollinearity issues. Table 5 also shows Durbin Watson's value of 1.910139. Because the value du $(1.67)<\mathrm{d}(1.910139)<4-\mathrm{du}(2.33)$ then the regression model does not contain auto correlates.

Table 5. Classic Assumption Test

\begin{tabular}{ccccc}
\hline \multicolumn{5}{l}{ Multicollinearity Test Results } \\
\hline & LOG(UMP) & LOG(PDRB) & LOG(I) & \\
\hline LOG(UMP) & 1.000000 & 0.146122 & 0.359374 & \\
LOG(PDRB) & 0.146122 & 1.000000 & 0.395702 & \\
LOG(I) & 0.359374 & 0.395702 & 1.000000 & \\
\hline Heteroscedasticity Test Results & & & \\
\hline Variable & Coefficient & Std. Error & t-Statistic & Prob. \\
\hline C & 7.316670 & 5.162388 & 1.417303 & 0.1658 \\
LOG(UMP) & -1.557550 & 2.223159 & -0.700602 & 0.4885 \\
LOG(PDRB) & -0.583479 & 0.421714 & -1.383588 & 0.1758 \\
LOG(I) & 1.576293 & 1.841920 & 0.855788 & 0.3983 \\
\hline Auto Correlation Test Result & & & \\
\hline R-squared & 0.999816 & Mean dependent var & 8869.964 \\
Adjusted R-squared & 0.999772 & S.D. dependent var & 19852.85 \\
S.E. of regression & 1.090111 & Sum squared resid & 39.21527 \\
F-statistic & 22439.14 & Durbin-Watson stat & 1.910139 \\
Prob(F-statistic) & 0.000000 & Mean dependent var & \\
\hline
\end{tabular}

\section{Hypothesis Test}

Probability values in hypothetical tests are conducted with several tests, including an individual regression coefficient test (t-test), overall regression coefficient test (F-test), and determination coefficient test $\left(\mathrm{R}^{2}\right)$. The $\mathrm{t}$-statistical test aimed to determine the effect of each free variable (UMP, PDRB, and investment variable) partially on the absorption of industrial sector labor in Java in 2013-2019. At the significance stage 5\% $(\alpha=0.05)$, and $\mathrm{df}(\mathrm{n}-\mathrm{k}-1)=38$ obtained t-table of 1.687. Based on the test results using Eviews 10 software, t-test results showed coefficients and t-statistical values, as presented in table 6 .

Table 6. t-statistic Test Result

\begin{tabular}{ccccc}
\hline Variable & Coefficient & t-statistic & t-tabel & Conclusion \\
\hline UMP & -0.874935 & -250.1811 & 1.687 & Reject Ho \\
PDRB & 0.561902 & 173.2863 & 1.687 & Reject Ho \\
Investment & 0.821413 & 261.7905 & 1.687 & Reject Ho \\
\hline
\end{tabular}

Table 6 shows that the UMP variable negatively affects labor absorption. This is indicated by the t-count value of 250.1811 greater than t-table 1.687 so that $\mathrm{HO}$ is rejected and $\mathrm{Ha}$ is accepted. The PDRB variable positively affects labor absorption indicated by the t-count value of 173.2863 greater than the $\mathrm{t}$-table of 1.687 so that $\mathrm{H} 0$ is rejected and $\mathrm{Ha}$ is accepted. Investment positively affects labor absorption indicated by the $t$-count value of 261.7905 , more significant than the t-table of 1.687 so that $\mathrm{HO}$ is rejected and $\mathrm{Ha}$ is accepted.

Furthermore, from F-statistic test result shows that the F-statistical value is 22,439.14. The F-statistical value is greater than the F-table value at a significance level of 5\%, so Ha is accepted. So it can be concluded that the variables of PDRB, UMP, and Investment together affect labor absorption. The coefficient in the estimated result, $\mathrm{R}^{2}$, indicates a value of 0.999816 . This means 
that $99.98 \%$ of workforce absorption can be explained by variable PDRB, UMP, and Investment. At the same time, $0.02 \%$ can be explained by variables outside of research.

\subsection{Interpretation of Individual Fixed Effect Methods}

The results of the interpretation of individual fixed effect methods in six Provinces in Java can be seen in table 7 .

Table 7. Interpretation of Individual Fixed Effect

\begin{tabular}{|c|c|c|c|}
\hline \multicolumn{3}{|c|}{ Variable } & Coefisient \\
\hline \multicolumn{3}{|c|}{$\mathrm{C}$} & 8.399585 \\
\hline \multicolumn{3}{|c|}{ UMP } & -0.874935 \\
\hline \multirow{2}{*}{\multicolumn{3}{|c|}{$\begin{array}{c}\text { PDRB } \\
\text { Investment }\end{array}$}} & 0.561902 \\
\hline & & & 0.821413 \\
\hline \multirow[t]{2}{*}{ No } & Fixed Effect (Cross) & Effect & \\
\hline & Province & Effect & Coeficient \\
\hline 1 & DKI Jakarta & -1.144982 & 9.544567 \\
\hline 2 & Jawa Barat & 0.363777 & 8.035808 \\
\hline 3 & Jawa Tengah & 0.512786 & 7.886799 \\
\hline 4 & DI Yogyakarta & 0.225676 & 8.173909 \\
\hline 5 & Jawa Timur & 0.238952 & 8.160633 \\
\hline 6 & Banten & -0.196209 & 8.595794 \\
\hline
\end{tabular}

Table 7 shows the value of the Fixed Effect coefficient of six Provinces in Java. Each coefficient value of the provincial Fixed Effect is different. The table also explains that free variables, namely PDRB and Investment, positively influence bound variables, namely labor absorption. UMP has a negative influence on the narrowing of industrial sector labor in six provinces in Java. The table also shows that the four Provinces with positive Fixed Effect coefficient values are West Java, Central Java, DI Yogyakarta, and East Java. This indicates that UMP, PDRB, and Investment are not the main factors in labor absorption in the six Provinces. In the absence of these three variables, other sectors or other economic variables can increase labor absorption. Besides, the two provinces have negative Fixed Effect coefficient values, namely DKI Jakarta and Banten. The results showed that the variables of UMP, PDRB, and Investment in the two Provinces were already well-executed and affected labor absorption. These results show that UMP, PDRB, and Investment variables strongly influence industrial sector labor absorption.

Table 8. Antilog of Labor Absorption Value without the influence of PDRB, UMP, and Investment

\begin{tabular}{clcc}
\hline \multirow{2}{*}{ No } & \multirow{2}{*}{ Province } & \multicolumn{2}{c}{ Coefficient } \\
\cline { 3 - 4 } & & Log & Antilog \\
\hline 1 & DKI Jakarta & 9.54 & $3,467,368,505$ \\
2 & Jawa Barat & 8.03 & $107,151,931$ \\
3 & Jawa Tengah & 7.88 & $75,857,758$ \\
4 & DI Yogyakarta & 8.17 & $147,910,839$ \\
5 & Jawa Timur & 8.16 & $144,543,977$ \\
6 & Banten & 8.59 & $389,045,145$ \\
\hline
\end{tabular}

After the accumulation between $\mathrm{C}$ and individual effect, it can be seen that Central Java Province, with the lowest coefficient results, has better labor absorption compared to the other five provinces. This shows that UMP, PDRB, and Investment in Central Java also affect industrial sector labor absorption. Before transforming into a $\log$ form, individual $\mathrm{C}$ accumulation data present in the following table 8 . Table 8 shows that the fixed effect value after being transformed 
in $\log$ form is 9.54 to $3,467,368,505$ after transformation into the antilogue. This means that without PDRB, UMP, and Investment, the workforce's absorption in DKI Jakarta province is $3,467,368,505$.

\subsection{The Effect of PDRB on Labor Absorption}

The results showed that PDRB had a positive effect on labor absorption. The results of this study support the results of research conducted by Budiarto \& Dewi (2015), Dimas \& Woyanti (2009), Hartono et al. (2018), Indradewa \& Natha (2015), Ziyadaturrofiqoh et al. (2018), as well as Widjajanto \& Agus ( 2020) PDRB reflects economic growth (the increase in output generated). The increase in PDRB leads to more significant employment opportunities. This result is similar to the economic growth theory put forward by Solow (2010), which states that national product growth is determined by capital growth and labor growth, technological advances, improved skills, and labor skills. The addition of capital impacts increasing business activities to expand its jobs (Budiarto \& Dewi, 2015; Hartono et al., 2018). Besides, the addition of capital can make the company develop technology and improve the workforce's skills (Indradewa \& Natha, 2015; Widjajanto \& Agus, 2020).

\subsection{The Effect of UMP on Labor Absorption}

Keynes mentioned that government involvement in the labor market could increase the demand for the number of workers. However, the results of this study show that UMP negatively impacts the absorption of labor. The results showed that UMP negatively affects labor absorption. The results of the study supported the findings of Akpansung \& Gidigbi (2014), Indradewa \& Natha (2015), Putri \& Soelistyo (2018), Wihastuti \& Rahmatullah (2018), and Wilis (2016) which found that wage levels had a negative influence on labor absorption. These results show conformity with the research hypothesis that UMP negatively affects labor absorption. Changes in wage rates affect its high production costs (Akpansung \& Gidigbi, 2014; Indradewa \& Natha, 2015; Putri \& Soelistyo, 2018; Wihastuti \& Rahmatullah, 2018; Wilis, 2016).

Rising wages increase the company's production costs, which increases the price per unit of goods produced. Rising prices of goods led the market to choose other products that led to many unsold goods, low demand for goods led manufacturers to lower production numbers and targets. The impact of declining production is the decrease in the workforce that the company needs. This is similar to the classic theory that UMP negatively relates to labor absorption (Putri \& Soelistyo, 2018).

\subsection{The Effect of Investment on Labor Absorption}

The results showed that investment had a positive effect on labor absorption. This study's results are consistent with the results of research conducted by Putri \& Soelistyo (2018) and Romdhoni (2017) mentioning that the increase in investment has a positive effect on labor absorption. Efforts to encourage investment are one step that can increase job opportunities (Tapparan, 2017). Increased investment can increase production capacity, which will affect the high demand for labor (Putri \& Soelistyo, 2018). Absorption of labor and the creation of welfare of workers due to economic growth and the value of investment channeled evenly (Putri, Abdul, \& Rosmiayati, 2019). Balanced economic growth is economic growth that can affect labor growth and the same as an investment (Widjajanto \& Agus, 2020). Investments made by investors in both PMDN and PMA can be a source of capital for the company. Investment activities can increase the company's funding sources to obtain assets that can be used to increase the company's 
production capacity. Increased production capacity causes the company to need an additional workforce to carry out production activities. However, in Basriwijaya \& Maryoni (2015) research, variable investment negatively influences the absorption of labor. This is supported by a Keynesian theory, which states that interest rates are not critical in determining investment demand. It can be said, if the interest rate rises in the investment decrease, or the interest rate decreases, the investment rises.

\section{CONCLUSION AND RECOMMENDATION}

The study results managed to find the simultaneous influence of PDRB, UMP, and investment on labor absorption. PDRB and investment have a positive effect on labor absorption. This means the increase in GDP and investment through domestic investment or foreign investment can increase labor absorption. This is due to the increase in PDRB and investment able to increase consumer demand that the company responds to by increasing production capacity. In contrast to both research results for PDRB and investment, UMP negatively affects labor absorption. This is because the increase in UMP leads to increased employee salaries, which impacts the high cost of production. High production costs cause companies to raise selling prices that can impact products that are not competing in the market. The limitation of this study is the number of samples conducted only in six provinces in Java Island. Further research could use broader data to reflect labor conditions in Indonesia. Besides, research may also focus on the differences in the three variables' impact on different workers, namely the educated workforce, trained workforce, uneducated labor, and untrained workforce.

The government should be wise in increasing the standard for determining the need for a decent living, considering that the necessities of a decent life are a reference for determining the UMP. Besides, the government could adopt policies that affect the working force of the PDRB and investment variables. The amount of investment is expected to generate new jobs to absorb labor, reducing the number of existing unemployment. The provinces of DKI Jakarta and Banten hoped to adopt appropriate policies or continue to focus on increasing Investment and PDRB and decreasing the UMP because these three factors greatly influence employment absorption. Because if it can absorb labor, the number of unemployed will decrease, increasing the regional economic growth due to the reduction in the number of unemployed.

\section{REFERENCES}

Adisetiawan, \& Ahmadi, R. (2016). The Impact of Earning Management Against Market Reaction: Empirical Evidance from Indonesia. International Research Journal of Finance and Economics, 146, 112-128.

Akpansung, A. O., \& Gidigbi, M. O. (2014). Recent Banking Reforms in Nigeria : Implications on Sectoral Credit Allocation and Economic Growth. International Journal of Business and Social Science, 5(13), 91-104.

Basriwijaya, K. M. Z., \& Maryoni, H. S. (2015). Pengaruh Investasi, Inflasi, Suku Bunga dan Tingkat Upah Terhadap Penyerapan Tenaga Kerja Di Sektor Pertanian Propinsi Sumatera Utara. Jurnal Imiah Cano Ekonomos, 4(2), 89-96.

BPS. (2020). DI Yogykarta Dalam Angka.

BPS. (2020). Jawa Timur Dalam Angka.

Budiarto, A., \& Dewi, M. (2015). Pengaruh PDRB dan Upah Minimum Provinsi Terhadap 
Penyerapan Tenaga Kerja Melalui Mediasi Investasi di Provinsi Bali. E-Jurnal Ekonomi Pembangunan Universitas Udayana, 4(10), 1219-1246.

Budiarty, I. (2018). du Dampak Upah Minimum di Pasar Tenaga Kerja Industri Pengolahan Provinsi Lampung. Jurnal Ekonomi Pembangunan, 7(1), 121-144.

Dimas \& Woyanti, N. (2009). Penyerapan Tenaga Kerja di DKI Jakarta. Jurnal Bisnis Dan Ekonomi (JBE), 16(1), 32-41.

Fachriza, F. I., \& Moeliono, N. (2018). Pengaruh Produk Domestik Regional Bruto ( PDRB ) dan Upah Minimum Kota (UMK ) Terhadap Penyerapan Tenaga Kerja. Jurnal Ecodemica: Jurnal Ekonomi, Manajemen, dan Bisnis, 1(1), 36-43.

Hartono, R., Busari, A., \& Awaluddin, M. (2018). Pengaruh Produk Domestik Regional Bruto (PDRB) dan Upah Minimum Kota (UMK) Terhadap Penyerapan Tenaga Kerja. INOVASI Jurnal Ekonomi Keuangan dan Manajemen, 14(1), 36-43.

Hindun. (2019). Pendidikan, Pendapatan Nasional, dan Penyerapan Tenaga Kerja di Indonesia. Jurnal Pendidikan Ekonomi, Manajemen dan Keuangan, 3(1), 15-22.

Indradewa, I., \& Natha, K. (2015). Pengaruh Inflasi, PDRB dan Upah Minimum Terhadap Penyerapan Tenaga Kerja di Provinsi Bali. E-Jurnal Ekonomi Pembangunan Universitas Udayana, 4(8), 923-950.

Lokiman, D., Rotinsulu, D.Ch., \& Luntungan, A.Y. (2015). Pengaruh Upah Minimum Provinsi (UMP) dan Investasi Swasta Terhadap Penyerapan Tenaga Kerja dan Dampaknya Pada PDRB (ADHK) di Kota Manado Tahun 2003-2012. Jurnal Berkala Ilmiah Efisiensi, 15(01), 43-61.

Mankiw, N.G., Quah, Euston, \& Wilson, P. (2014). Pengantar Ekonomi (2nd ed.). Salemba Empat.

Pangastuti, Y. (2015). Analisis Faktor-Faktor Yang Mempengaruhi Penyerapan Tenaga Kerja di Provinsi Jawa Tengah. Economics Development Analysis Journal, 4(2), 203-211.

Putri, A. A., Abdul, K. S., \& Rosmiayati, C. (2019). Factors Affecting Labor Absorption: Case Study in South Sumatra Province. Modern Economics, 18(2019), 6-14.

Putri, N. A., \& Soelistyo, A. (2018). Analisis Pengaruh Upah, PDRB, dan Investasi Terhadap Penyerapan Tenaga Kerja di Kawasan Gerbangkertasusila Tahun 2012-2016. Jurnal Ilmu Ekonomi, 2, 357-371.

Romdhoni, A. H. (2017). Pengaruh Investasi Terhadap Penyerapan Tenaga Kerja di Jawa Tengah Tahun 2009-2013. Jurnal Ilmiah Ekonomi Islam, 3(2), 139.

Setiawan, D., Maulida, Y., \& Sandika, R. S. (2014). Pengaruh Investasi Terhadap Penyerapan Tenaga Kerja di Kabupaten Pelalawan. Jurnal Online Mahasiswa Fakultas Ekonomi Universitas Riau, 1(2), 1-16.

Sitompul, T., \& Simangunsong, Y. (2019). The Analysis of the Impact of GDP, FDI, Minimum Wage on Employment in Indonesia. International Journal of Management, Entrepreneurship, Social Science and Humanities, 2(2), 53-62.

Solow, R. M. (2010). A Contribution to the Theory of Economic Growth. Growth (Lakeland), $70(1), 65-94$.

Sudiarawan, K. A., \& Martana, P.A.H. (2019). Implikasi Hukum Pengaturan Upah Minimum Sektoral Kabupaten Badung Terhadap Pelaku Usaha Pada Sektor Kepariwisataan di Kabupaten Badung Provinsi Bali. Supremasi Hukum: Jurnal Penelitian Hukum, 28(1), 3356.

Sulistiawati, R. (2012). Pengaruh Investasi Terhadap Pertumbuhan Ekonomi dan Penyerapan 
Tenaga Kerja Serta Kesejahteraan Masyarakat di Provinsi di Indonesia. Jurnal Ekonomi, Bisnis dan Kewirausahaan, 3(1), 29-50.

Tapparan, S. R. (2017). Pengaruh Upah Minimum dan Investasi terhadap Kesempatan Kerja di Provinsi Sulawesi Selatan. Jurnal Ad'ministrare, 4(1), 7-14.

Widjajanto, T., \& Agus, I. (2020). Analisis Pengaruh Investasi dan PDRB Terhadap Peyerapan Tenaga Kerja di Provinsi Jawa Tengah Tahun 2018. Sosio e-kons, 12(1), 89-96.

Wihastuti, L., \& Rahmatullah, H. (2018). Upah Minimum Provinsi ( UMP ) Dan Penyerapan Tenaga Kerja di Pulau Jawa. Gamma Societa, 1(1), 96-102.

Wilis, R. (2016). Analisis Pengaruh Upah Minimum, Investasi Dan Pengeluaran Pemerintah Terhadap Penyerapan Tenaga Kerja Berdasarkan Pendidikan. El Dinar, 3(1), 12-26.

Ziyadaturrofiqoh, Zulfanetti, \& Safri, M. (2018). Pengaruh PDRB, Upah Minimum Provinsi dan Pengeluaran Pemerintah Terhadap Penyerapan Tenaga Kerja di Provinsi Jambi. E-Jurnal Ekonomi Sumberdaya dan Lingkungan, 7(1), 13-22. 